\title{
Brain Death Diagnosis and Management in the Pandemic: Expert Opinion of the Turkish Neurological Society Neurological Intensive Care Scientific Working Group
}

\author{
Pandemide Beyin Ölümü Tanısı ve Yönetimi: Türk Nöroloji Derneği Nörolojik Yoğun \\ Bakım Bilimsel Çalışma Grubu Uzman Görüşü
}

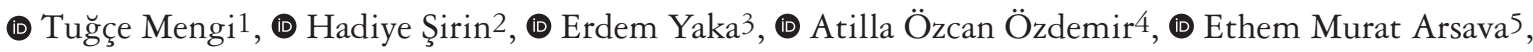
(1) Mehmet Akif Topçuoğlus

${ }^{1}$ Nigde Training and Research Hospital, Clinic of Neurology, Intensive Care Unit, Nigde, Turkey 2Ege University Faculty of Medicine, Department of Neurology, Neurology Intensive Care Unit, Izmir, Turkey 3Dokuz Eylul University Faculty of Medicine, Department of Neurology, Neurology Intensive Care Unit, Izmir, Turkey ${ }^{4}$ Osmangazi University Faculty of Medicine, Department of Neurology, Neurology Intensive Care Unit, Eskisehir, Turkey 5Hacettepe University Faculty of Medicine, Department of Neurology, Neurology Intensive Care Unit, Ankara, Turkey
\end{abstract}

\begin{abstract}
In the pandemic year, the number of brain death declarations decreased by more than $50 \%$ compared with previous years. The timely diagnosis of brain death is critical in terms of rational use of intensive care facilities, as well as organ transplantation. Apnea testing should not be omitted in patients with COVID-19, and can be performed either with apneic oxygenation method or ventilator-based spontaneous modes when standard prerequisites are met. Complete compliance with personal protection measures and prevention of the environmental escape of the expiratory air via tube clamping or filtering is essential. Other declaration processes should be conducted in accordance with the 2014 guidelines of the Turkish Neurology Association.
\end{abstract}

Keywords: Brain death, organ transplantation, CT angiography, aerosolization, apnea test

$\ddot{\mathbf{O z}}$

Pandemi yılında beyin ölümü deklarasyon sayısı önceki yıllara göre \%50'den fazla azaldı. Beyin ölümünün zamanında teşhisi organ nakli kadar yoğun bakım imkanlarının rasyonel kullanımı açısından da kritik önemdedir. Apne testi COVID-19 hastalarında standart ön koşullar sağlandı̆̆ında apneik oksijenasyon veya ventilatöre bağlı şekilde spontan modlarda gerçekleştirilebilir. Kişisel koruma önlemlerine eksiksiz uyum ve ekspirasyon havasının klempleme veya filtreleme ile hiçbir zaman ortama verilmemesi şarttır. Deklarasyondaki diğger süreçler Türk Nöroloji Derneği 2014 rehberine uygun şekilde gerçekleştirilmelidir.

Anahtar Kelimeler: Beyin ölümü, organ nakli, BT anjiyografi, aerosolizasyon, apne testi

\section{Introduction}

We have been experiencing the "Coronavirus Disease (COVID-19)" pandemic caused by the new type of coronavirus (SARS-CoV-2) for about 1 year. During this period, all over the world and in Turkey, profound changes in lifestyle, habits, education, politics, and economics have occurred. In the process, people's perspective on life, current and future, has changed, and death has begun to be considered more than ever (1).

In the pandemic, there has been radical change and transformation in all areas of the health sector, without exception.

Address for Correspondence/Yazışma Adresi: Mehmet Akif Topçuoğlu MD, Hacettepe University Faculty of Medicine, Department of Neurology, Neurology Intensive Care Unit, Ankara, Turkey

Phone: +90 3123051806 E-mail: mat@hacettepe.edu.tr ORCID: orcid.org/0000-0002-7267-1431

Received/Geliş Tarihi: 07.01.2021 Accepted/Kabul Tarihi: 04.02.2021

${ }^{\circ}$ Copyright 2021 by Turkish Neurological Society

Turkish Journal of Neurology published by Galenos Publishing House. 
A large part of the technical and workforce capacity of wards and intensive care units (ICUs) has been shifted to the struggle against the pandemic. However, the new problems added in the pandemic did not eliminate the old ones. In this context, transplantation practices have been dramatically affected $(2,3)$. Organ donation from cadavers for transplantation has significantly decreased $(3,4)$. In this article, the changes observed in brain death declaration in Turkey were identified and Turkish Neurological Society (TND), Neurological Intensive Care Working Group's suggestions on organ donation projection and diagnosis and declaration process of brain death in the pandemic were reviewed.

The Impact of the COVID-19 Pandemic on Brain Death Declaration Processes

Brain death is diagnosed in approximately one-tenth of comatose patients followed up in ICUs (5). The standard approach focused on the detection of potential donors and the early diagnosis of brain death is critical (6). However, the pandemic imposed its conditions and the standard protocols were stalled at many stages. Ultimately, there has been a significant decline in the number of organ donations and family permission all over the world and in Turkey in the pandemic period. The number of brain death declarations $(n=1379)$ in our country decreased by $40 \%$ in 2020 compared with the previous year and by $25 \%$ compared with the average of the last 10 years $(n=1840)$, and the family permission rate $(n=263)$ decreased by $50 \%$ in the pandemic year compared with the previous year and this decrease corresponded to a $25 \%$ decrease compared with the average of the last 10 years (Figure 1) (7).

Although the reasons for this decrease observed in the pandemic have not been studied specifically, the first cause that comes to mind is the decrease in the admission to hospital of neurocritical patients with the most common diagnoses causing brain death such as intracerebral hemorrhage, traumatic brain injury, subarachnoid hemorrhage, ischemic stroke, anoxic encephalopathy and brain tumor, and especially to ICUs (8). There was a reduction

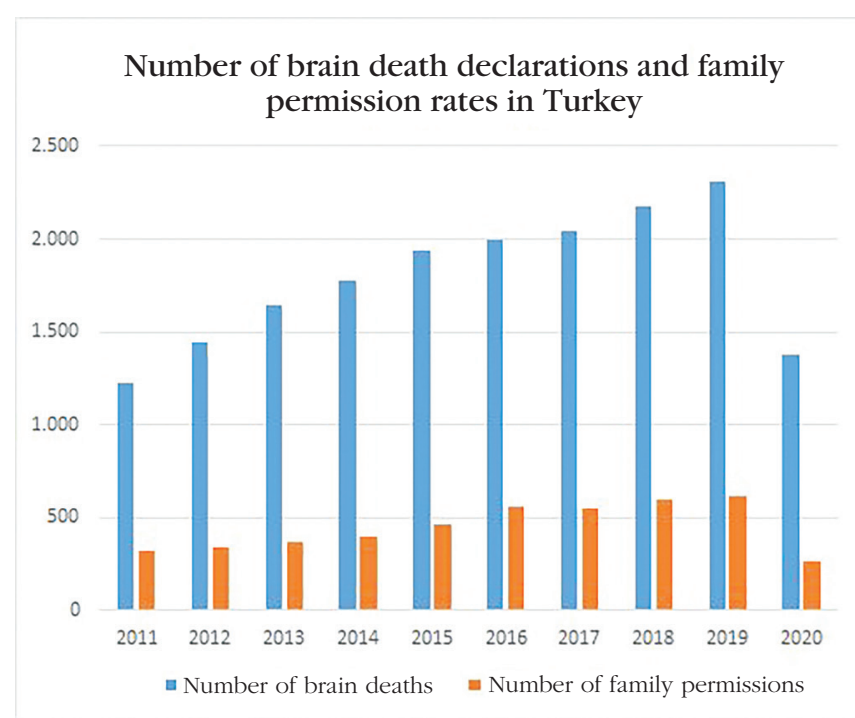

Figure 1. The dramatic decline in the number of brain death declarations and family permission rates in the pandemic year of over $50 \%$ in emergency department admissions due to trauma and other reasons during the curfew in the United Kingdom. This may be reflected in a decrease in the potential donor pool (4). On the other hand, logistical problems leading to prolongation of the time required to test potential donors and additional problems in involving families in the process may have contributed to the observed decrease $(8,9)$. Potential donor losses due to positivity as a result of COVID-19 screening or due to prolongation have been reported. Organ harvesting cannot be performed from patients positive for COVID-19 (10). In addition, many expert teams involved in organ donation processes must be assigned to intensive care and other COVID-19 related projects (9). Although there are surgeons who will perform organ transplantation, the conversion of many operating rooms to intensive care rooms and the limited number of operating rooms left for emergency operations may have contributed to the decrease in transplantation rates $(4,11)$.

Brain Death Diagnosis and Apnea Test in a Patient with Confirmed or Suspected COVID-19

The main clinical signs of brain death are "coma", "loss of brainstem reflexes" and "apnea" $(12,13)$. It is safe to perform neurologic examinations on patients diagnosed as having COVID-19 by complying with standard personal protection rules (14). Our experience shows that it is difficult to monitor these patients under mechanical ventilation. With effective sedoanelgesia, even with the wise use of modes, persistent hypoxemia in some patients seems to be the reality of this disease. In light of this information, it should not be forgotten that keeping sedoanelgesia at the lowest possible level, performing neurologic examinations by discontinuing it for an effective period, and carefully evaluating brainstem reflexes are very important in terms of detecting brain death. Concentrating only on effective blood gas values under prolonged sedoanelgesia may result in a patient with brain death not being recognized.

Although there are various methods defined for apnea testing, the most preferred method is the "traditional apneic oxygenation" technique. Apneic oxygenation analysis is performed by placing an oxygen cannula in the endotracheal tube and giving oxygen into the trachea at the carina level. Meanwhile, the patient is removed from the mechanical ventilator. After the apnea test is completed, the patient is reconnected to the ventilator (15). However, in this method, in which the oxygen insufflation technique is used, there is a high risk of aerosol formation. The risk can be reduced by clamping the endotracheal tube while inserting a T-piece and by attaching a heat-moisture exchanger (HME) filter to the expiration end (16). Another method is to provide continuous positive airway pressure (CPAP) via a T-piece connected to a positive end-expiratory pressure valve. In this method, the patient is reconnected to the ventilator after the apnea test is completed. Instead of this second method, apnea ventilation can be performed with CPAP while the patient is directly connected to the ventilator. In this case, the trigger setting should be optimized and care should be taken in terms of auto-triggering (17). If the apnea test is to be performed with a T-piece or oxygen insufflation technique, the team should perform this test with full personal protective equipment (PPE) (18). It must be performed in this way unless the diagnosis of COVID-19 has been definitely been ruled out.

The apnea test performed under appropriate conditions is also safe in patients with COVID-19. Conditions to be met before 
starting apnea testing are not different in patients with COVID-19. Use of PPE and proper filtering are essential. As in other patients, complications such as hypoxemia, hypotension, cardiac arrhythmia, and rarely pneumothorax, were reported (19). Contrary to the fact that it has been proposed by some authors in the literature without showing evidence (20), in patients with COVID-19, it does not seem appropriate to perform diagnostic or other group supportive tests such as catheter or computed tomography (CT) angiography, which diagnose brain death by directly documenting cerebralcirculatory arrest by skipping the apnea test, due to the risks in patient transport. These should be peformeded in accordance with the pre-declaration rules in patients with positive apnea test. At this point, it is useful to emphasize once again that in patients in whom apnea test cannot be performed, diagnosis can be made using electroencephalography or transcranial Doppler (12).

Selection of Supportive Tests for the Diagnosis of Brain Death in a Patient with Confirmed or Suspected COVID-19

Brain death diagnosis begins with the occurrence of clinical criteria and is completed with the documentation of cerebral circulatory arrest (12). Diagnosis and declaration processes vary significantly around the world (13). In our country, the criteria published by the TND in 2014 draw a very clear path. Accordingly, in the patient whose apnea test is positive, cerebral circulatory arrest is documented with CT-angiography and the declaration process is initiated (12). If the apnea test is not completed, CT angiography can be performed under more favorable conditions instead of repeating the test. On the other hand, in patients with severe COVID-19 involvement, it is likely that the conditions required for the apnea test cannot be met. In these two patient groups, it is rational to request CT angiography after detecting sonogram patterns compatible with cerebral circulatory arrest by transcranial Doppler ultrasonography in the ICU because in-hospital transport has the potential to increase the risk of aerosolization and transmission (6).

\section{Organ Transplantation Process in the COVID-19 Pandemic}

During the pandemic period, there are many successful cadaveric organ transplantation experiences published from the world and our country $(21,22)$. The strategy can be summarized as follows: After the patient's relatives give consent for organ donation, the patient's contact history and COVID-19 symptomatology, thorax CT findings and SARS-CoV-2 polymerase chain reaction (PCR) result should be reviewed once again. PCR is often requested twice with an interval of 24 hours. When it is documented that all the parameters counted are negative or not compatible with COVID-19, the organ harvesting phase proceeds. PPE should be worn strictly and aerosolization and isolation precautions should be applied carefully at all stages. Chest diseases, infectious diseases, and clinical microbiology departments should be included in the process. In this way, the transplantation process is completed in its standard form (23).

\section{Controversial Issues and Solution Suggestions}

In the pandemic, in patients without COVID-19, it is seen that there is no change in the declaration process of brain death except the logistics. However, even if the risk of contamination is low, the procedure brings additional measures such as protected/ modified apnea test and pre-transplant repeat of the PCR test, which emphasize the safety of healthcare professionals and recipients against the possibility of contamination. On the other hand, in patients with COVID-19, brain death should be declared on time and at all times. The fact that organ donation is not currently possible in these patients should not change this situation. In the brain death declaration process, eligibility for organ transplantation should not be a criterion. In other words, whatever the patient's condition, brain death should be detected and reported. Transplantation after waiting for a PCR test to become negative and antibody test to become positive in patients with COVID-19 in whom brain death is declared is not a realistic strategy because the patient and recipient are immunosuppressive and that there is no in vitro viral inactivation method (24). However, it is clear that the declaration is critical for the detection of patients with COVID-19. In this context, focused neurologic examinations and apnea tests or diagnostic/confirmatory examinations as outlined above do not pose an additional risk when the patient is transported in the hospital under appropriate conditions.

\section{Ethics}

Peer-review: Externally peer-reviewed.

\section{Authorship Contributions}

Concept: T.M., H.Ş., E.Y., A.Ö.Ö., E.M.A., M.A.T., Design: T.M., H.Ş., E.Y., A.Ö.Ö., E.M.A., M.A.T., Data Collection or Processing: T.M., H.Ş., M.A.T., Analysis or Interpretation: T.M., H.Ş., E.Y., A.Ö.Ö., E.M.A., M.A.T., Literature Search: T.M., H.Ş., E.Y., A.Ö.Ö., E.M.A., M.A.T., Writing: T.M., H.Ş., M.A.T.

Conflict of Interest: No conflict of interest was declared by the authors.

Financial Disclosure: The authors declared that this study received no financial support.

\section{References}

1. Acar T, Demirel EA, Afşar N, et al. The COVID-19 from neurological overview. Turk J Neurol 2020;26:56-106.

2. Angelico R, Trapani S, Manzia TM, et al. The COVID-19 outbreak in Italy: Initial implications for organ transplantation programs. Am J Transplant 2020;20:1780-1784.

3. Dominguez-Gil B, Fernandez-Ruiz M, Hernandez D, et al. Organ donation and transplantation during the COVID-19 pandemic: A summary of the Spanish experience. Transplantation 2021;105:29-36.

4. Manara AR, Mumford L, Callaghan CJ, Ravanan R, Gardiner D. Donation and transplantation activity in the UK during the COVID-19 lockdown. Lancet 2020;396:465-466.

5. Senouci K, Guerrini P, Diene E, et al. A survey on patients admitted in severe coma: implications for brain death identification and organ donation. Intensive Care Med 2004;30:38-44.

6. Kahveci E, Arsava EM, Bozoklar CA, et al. Beyin ölümü kavramı ve organ donasyonu temel ilkelerinin olgularla gözden geçirilmesi. In: Kahveci E, Bozoklar, CA, Topcuoglu, MA. (eds). Beyin ölümünden organ nakline: Temel ilkeler ve pratik uygulamalar. Ankara: Türkiye Organ Nakli Vakf, 2015:241-286.

7. Organkds. Access Date: 01.01.2021. Available from: https://organkds. saglik.gov.tr/dss/PUBLIC/Brain_Death.aspx

8. Dominguez-Gil B, Coll E, Fernandez-Ruiz M, et al. COVID-19 in Spain: Transplantation in the midst of the pandemic. Am J Transplant 2020;20:2593-2598.

9. Valdes E, Agarwal S, Carroll E, et al. Special considerations in the assessment of catastrophic brain injury and determination of brain death in patients with SARS-CoV-2. J Neurol Sci 2020;417:117087. 
10. Kates OS, Fisher CE, Rakita RM, Reyes JD, Limaye AP. Use of SARS-CoV-2 infected deceased organ donors: Should we always “just say no?". Am J Transplant 2020

11. Picard C, Le Pavec J, Tissot A, Groupe Transplantation Pulmonaire de la Societe de Pneumologie de Langue Francaise SPLF. Impact of the COVID-19 pandemic and lung transplantation program in France. Respir Med Res 2020;78:100758.

12. Arsava EM, Demirkaya Ş, Dora B, et al. Turkish Neurological SocietyDiagnostic guidelines for brain death. Turk J Neurol 2014;20:101-104.

13. Greer DM, Shemie SD, Lewis A, et al. Determination of brain death/death by neurologic criteria: the World Brain Death Project. JAMA 2020;324:10781097.

14. Kirschen MP, McGowan N, Topjian A. Brain death evaluation in children with suspected or confirmed Coronavirus disease 2019. Pediatr Crit Care Med 2020. doi: 10.1097/PCC.0000000000002650. Online ahead of print.

15. Arsava E, Topcuoglu M. Beyin ölümü Tanısı: Klinik ve laboratuar. In Kahveci E, Bozoklar, CA, Topcuoglu, MA. (eds). Beyin ölümünden organ nakline: temel İlkeler ve pratik uygulamalar. Ankara: TONV: Türkiye Organ Nakli Vakfi, 2015:93-116.

16. Radaideh Y, Garg R, Abdalla AA, et al. Challenges in brain death determination and apnea testing for patients with COVID-19. J Stroke Cerebrovasc Dis 2020;29:105419.
17. Wijdicks EF, Manno EM, Holets SR. Ventilator self-cycling may falsely suggest patient effort during brain death determination. Neurology 2005;65:774

18. Migdady I, Rae-Grant A, Greer DM. Brain death evaluation during the pandemic. Neurology 2020;95:693-694.

19. Zantah M, Dominguez Castillo E, Townsend R, Dikengil F, Criner GJ. Pneumothorax in COVID-19 disease- incidence and clinical characteristics. Respir Res 2020;21:236.

20. Kapoor I, Prabhakar H, Mahajan C. COVID-19 and diagnosing brain death: An ambiguity. Turk J Anaesthesiol Reanim 2020;48:436-437.

21. Vargas M, Iacovazzo C, Servillo G. Additional suggestions for organ donation during COVID-19 outbreak. Transplantation 2020;104:1984-1985.

22. Yakar MN, Istan P, Gurkok MC, et al. Management of an organ donation process in COVID-19 pandemic: First case of Turkey. Turk J Anaesthesiol Reanim 2020;48:244-247.

23. Azzi Y, Bartash R, Scalea J, Loarte-Campos P, Akalin E. COVID-19 and solid organ transplantation: A review article. Transplantation 2021;105:37-55.

24. Paggiaro AO, Carvalho VF, Gemperli R. Effect of different human tissue processing techniques on SARS-CoV-2 inactivation-review. Cell Tissue Bank 2021;22:1-10. 